\title{
The Bible and the justification of apartheid in Reformed circles in the 1940's in South Africa: Some historical, hermeneutical and theological remarks ${ }^{1}$
}

\author{
Vosloo, Robert R \\ Stellenbosch University \\ rrvosloo@sun.ac.za
}

\begin{abstract}
This article focuses on the way the Bible was used in the 1940s in some Reformed theological circles in South Africa as part of the discourse to justify apartheid. Attention is also given to some voices critical of this endeavour. The article therefore offers a close reading of influential texts by prominent theologians who provided a biblical justification of apartheid, such as JD du Toit (Totius) and EP Groenewald. In addition, the article attends to some of the writings of theologians such as BJ Marais and BB Keet, who strongly opposed any attempt to justify apartheid in this manner. The article is especially interested in identifying the constructions of identity and otherness that seem to be operative in the discourse connected to the biblical justification of apartheid during this period.
\end{abstract}

Keywords

Bible, apartheid, Reformed theology, South Africa, 1940's

\section{Introduction}

Reformed theology in South Africa has an ambivalent history and legacy, also with regard to the way in which the Bible was read and interpreted. It is a well-known fact that the Bible was used in some Reformed circles to justify the policy and practice of apartheid. However, a few prominent pastors and academics also expressed strong criticism of the attempts to use the Bible in this manner. The focus of this article is on the way the Bible was used in

1 This article is based on a paper that was read at Biblica's Conversation on the Bible, held at the Stellenbosch Institute for Advanced Studies (STIAS), 24-25 March 2015. 
the 1940s in some Reformed theological circles in South Africa to justify apartheid, with specific reference to some influential texts by prominent theologians such as JD du Toit (Totius) and EP Groenewald. In addition, the article attends to some of the writings of theologians such as BJ Marais and BB Keet who strongly opposed any attempt to justify apartheid in this manner. In the process attention is given to the constructions of identity and otherness that seem to be operative in this discourse.

\section{The Bible, separation, segregation and apartheid}

'Give me a Bible text,' says the opponent of our colour policy, 'a text that proves that segregation is in agreement with the utterances of Holy Scripture.' 'I have no text,' is my answer. 'Then I have won the case, says the advocate for equality' ... I answer: ... 'I don't have a text, but I have the Bible, the whole Bible. My argumentation would proceed from Genesis to Revelation. ${ }^{2}$

With these words the well-known Afrikaans poet and Bible translator Prof $\mathrm{J}$ D du Toit (better known as Totius) begins his famous address on "Die Godsdienstige Grondslag van ons Rassebeleid" [The Religious Foundation of our Race Policy] at the National People's Congress ("Volkskongres") on Race Policy, held in Bloemfontein in 1944. Totius, a prominent theologian in the Gereformeerde Kerk (today known as the Reformed Churches in South Africa), goes on to present his argument to defend racial segregation on biblical grounds, starting - as promised - with Genesis.

In Genesis 1, Totius argues, we read that God creates a beautiful unity. But how does God do this? God acts as the Hammabdil, i.e. the Separator or Divider ("Skeidingmaker"). As the "great Divider", God separates light and darkness, the dry land from the waters, the living creatures according to their kind. God created things not as a mixed mass, but as separated and segregated. Drawing on Acts 17:26, Totius admits that God created the nations out of one blood, but notes that this verse further states that God determined the boundaries of their territory. However, in Genesis 11 we read how the tower builders, drawing on their own wisdom and

2 Du Toit, JD and Du Toit, S, Die Afrikaanse Rassebeleid en die Skrif: Artikels van prof. dr $J D d u$ Toit en prof $d r d u$ Toit (tweede druk) (Potchefstroom: Pro Rege Bpk, 1955), 5. 
in resistance to God's command ("in hulle eiewysheid en verset"), did not want to trek any further, and wanted to remain one nation with one language. But, according to Totius, God again acts as the "Divider" ("Skeidingmaker") by creating a confusion of languages and dispersing the nations over the whole earth (Genesis 11:9). Therefore the nations should stand their ground ("hulleself handhaaf") against this Babylonian spirit of unification ("die Babiloniese gees van eenmaking"). For Totius, God willed the coming into being of the nations, but not the formation of empires (cf. Dan 7; Rev 17:13). ${ }^{3}$

Given this emphasis on the idea that God (as Divider) created the nations, Totius then goes on to challenge the idea of "gelykstelling" (equalisation) between the races as defended by what he calls "die humaniteitsmense" ("the humanist people"), with their references to texts such as Colossians 3:11 and Galatians 3:28. The point for Totius here is that the unity depicted in these texts refers to a spiritual unity in Christ in which distinctions and separations remain intact. ${ }^{4}$

Readers of Totius's text today will probably be struck by his reference to Africa as a "dark swamp" ("donker moeras") that is set over against "civilisation," as well as his depiction of the Afrikaner nation ("Boerenasie") as a "new type" that came into being out of a remarkable and miraculous convergence of bloodlines. ${ }^{5}$

The heart of Totius's argument for racial separation lies in his emphasis on the idea that what God has separated we should not put together. God wills pluriformity, and unity is to be viewed as a spiritual unity in Christ. Hence he wants no equalising of races ("geen gelykstelling”), because this reflects the Babylonian agenda of imposing equalisation where there is in fact no equality. ${ }^{6}$

3 This idea that God willed the nations but not empires is also forcefully presented in the sermons of Reverend CR Kotzé from Bloemfontein. One of his sermons is even entitled "God maak die nasies en die duiwel maak die Empire" [God created the nations by the Devil created the Empire]. See Kotzé, CR, Die Bybel en ons Volkstryd: Preke 1930-1946 (Bloemfontein: SACUM Beperk, n.d.), 8-11.

4 Du Toit and Du Toit, Die Afrikaanse Rassebeleid en die Skrif, 9-10.

5 Du Toit and Du Toit, Die Afrikaanse Rassebeleid en die Skrif, 13.

6 Du Toit and Du Toit, Die Afrikaanse Rassebeleid en die Skrif, 14. 
The idea of "geen gelykstelling" stands out as a dominant motif in the discourse on racial issues in South Africa. It found expression, for instance, in the Mission Policy of the Dutch Reformed Church in 1935, where we read:

The Afrikaner's traditional fear of equalisation ("gelykstelling") between black and white was born from his aversion to the idea of racial mixing. The Church declares itself straightforwardly opposed to this mixing and to everything that promotes ... While the church does declare itself opposed to social equalisation ("gelykstelling") in the sense of the disregard for the racial and colour differences between blacks and whites in daily life, it wishes to encourage and promote social differentiation and cultural segregation to the benefit of both sections. ${ }^{\text {? }}$

Totius supports this idea of "geen gelykstelling," as well as the emphasis on another dominant motif in the discourse on race relationships, namely the aversion of proponents of segregation to racial "blood mixing" ("bloedvermenging"). Totius is thus not only opposed to "gelykstelling," but also to "verbastering" (bastardisation) through miscegenation. In this regard Totius recommends a pamphlet by Rev. J.G. Strydom (who was also a speaker at the "Volkskongres" of 1944) on "Die rassevraagstuk en die toekoms van die blanke in Suid-Afrika" [The Race Question and the Future of Whites in South Africa], commenting that every household in South Africa should have a copy of this booklet. This booklet by Strydom, the mission secretary of the Dutch Reformed Church in the Orange Free State, was published in 1942 and copies were indeed sent to every church council in the Free State to distribute for free. This text makes for interesting reading. The target of Strydom's booklet is also the idea of "verbastering." Strydom reaches the conclusion

that the white man's survival can only be guaranteed if he ... maintains the strict policy of the old folks of strict apartheid in social

7 See "Sendingbeleid van die Gefedereerde Ned. Geref. Kerke, 1935" in Lombard, RTJ, Die Nederduitse Gereformeerde Kerke en Rassepolitiek, met spesiale verwysing na die jare 1948-1961 (Pretoria: NGK Boekhandel, 1981), 272-273. Cf. Elphick, R, The Equality of Believers: Protestant Missionaries and the Racial Politics of South Africa (Pietermaritzburg: University of Kwazulu-Natal Press, 2012), 232. 
life, and not sink to the level of the barbarian, and if mixed marriages are prohibited and interracial intercourse is severely punished. ${ }^{8}$

It is also interesting to note that Strydom argues for objectivity and justice in dealing with the race question: "On the political level one should deal with the race question in a purely objective manner, in order to let justice prevail." However, for him it is the policy of apartheid that provides the only honest, just and practical policy ("die enigste eerlike, regverdige en praktiese beleid") for whites and blacks to live together in one country. Strydom challenges those who - in his view - falsely, and on Biblical grounds, argue against social apartheid, and proffered his belief that one can argue on the basis of God's Word that God willed separate nations, albeit that all those who are saved are one in Christ. Moreover, Strydom argues that the policy of apartheid is the only policy that protects racial purity, an emphasis that Totius shares. ${ }^{10}$

In his address at the "Volkskongres" in 1944 Totius further refers to the idea of Christian guardianship ("Christelike voogdyskap"), another central motif in the discourse on race in South Africa in the 1940s. ${ }^{11} \mathrm{He}$ comments in this regard:

Fellow South Africans, here is the calling from God on high, namely to nurture the native in his coming of age ... The wonderful God who guided our fathers as torch bearers for black Africa will also

8 Strydom, JG, Die Rassevraagstuk en die toekoms van die blankes in Suid-Afrika (NG Kerk in die OVS, nd), 28.

9 Strydom, Die Rassevraagstuk en die toekoms van die blankes in Suid-Afrika, 28.

10 Strydom, Die Rassevraagstuk en die toekoms van die blankes in Suid-Afrika, 42.

11 It would be a mistake to think that the notion of guardianship ("voogdyskap") was used by all commentators in the same way. Prof. Gerdener, an influential missiologist from Stellenbosch, also made the case for "voogdyskap" in several of his editorials in the quarterly Op die Horison [On the Horizon] in the late 1930s and early 1940s, emphasising that guardianship requires fairness and sacrifice: "We should practise our guardianship as whites in a truly altruistic way, so that both sections of the population are convinced of our good will". See Op die Horison 1/ 2, April 1939, 98. Several articles in the early 1940 in Op die Horison dealt with this concept of guardianship. Dr AH Murray, for instance, wrote on the "Voorwaardes van Voogdyskap" [The Prerequisites of Guardianship], arguing that the notion of "voogdyskap" should replace the word segregation in everyday parlance. And in June 1944 Rev C. B. Brink wrote on "Die betekenis van Christelike voogdyskap" [The Meaning of Christian Guardianship], discussing in his article the basis and obligations of guardianship. See Brink, C. B., "Die Betekenis van Christelike Voogdyskap," Op die Horison 6/2, June 1944:50-58. 
lead and inspire us under possibly even more difficult conditions to be bearers of light where the darkness still prevails. ${ }^{12}$

The "Volkskongres" in Bloemfontein in 1944 was not the first time that a scriptural justification was given for apartheid. ${ }^{13}$ What was important about the 1944 congress, though, was that it brought discussions that were found in a small circle of academics and pastors to a wider public. The decisions taken at the "Volkskongres" draw together several of the motifs already highlighted from Totius's address. The congress decided

That it is to the benefit of whites as well as blacks that a policy of apartheid be followed ... And that it is the duty of the whites to act as guardians over the black races... And that in the best interest of all races there shall be no further mixing of blood. ${ }^{14}$

The decisions of the "Volkskongres" are presented as defensible on scriptural, scientific and historical grounds. The argument is thus made that the policy is based on the Bible, that it is scientifically grounded ("wetenskaplik gefundeerd"), and that it is in line with the experience of centuries of close contact with the "non-white" races (thus an argument derived from experience and history). We also see some clear evidence of "constructions of an enemy" in the congress decisions, with its critique of liberalism, communism, Roman Catholicism and "foreign" mission societies, because the influence of these forces will lead to the eradication of natural boundaries and that this, in turn, will create social chaos. ${ }^{15}$

\section{Just racial apartheid?}

The 1944 congress was a key event in which the scriptural justification of apartheid was given a powerful explication and the congress led to the dissemination of these ideas to a wider audience. In 1947 another

12 Du Toit and Du Toit, Die Afrikaanse Rassebeleid en die Skrif, 19-20.

13 See, for instance, Van der Merwe, WJ, "Segregasie en Aparte Woongebiede," Op die Horison, March 1942: 15-22.

14 For the official decisions of the congress, see "Die Rassebeleid van die Afrikaner: Besluite van die Volkskongres, Bloemfontein, September 1944", Op die Horison, March 1945 1:16-23.

15 "Die rassebeleid van die Afrikaner", 22. 
influential "Volkskongres" was held in Johannesburg, this time dealing with the rapid Afrikaner urbanisation, including the challenges faced in a competitive labour market. This conference was preceded by the publication of the extensive and influential report called Kerk en Stad ["Church and City", 1947]. The last chapters of this report affirm the view that the proposed solutions to deal with the challenges of Afrikaner urbanisation included the rejection of the mixing of races and the critique of mixed neighbourhoods. ${ }^{16}$ At the 1947 "Volkskongres," which was held from 1-4 July 1947 at the campus of the University of the Witwatersrand, a series of decisions was taken that relate to racial policy. The congress stated, for instance, as its firm position that a conscious and extensive policy of racial separation ("rasse-apartheid") should be applied to every sphere of society. ${ }^{17}$

One of the speakers at the 1947 conference was Dr Geoff Cronjé, a professor of sociology from the University of Pretoria. His paper on "Racial Policy" ("Rassebeleid") was later expanded and published in the book Regverdige rasse-apartheid [Just Racial Apartheid], a book that included chapters by Dr W. Nicol and Prof. E. P, Groenewald. Prof. Groenewald, a respected New Testament scholar from the University of Pretoria, used as the basis for his chapter on "Apartheid en Voogdyskap in die lig van die Heilige Skrif" [Apartheid and Guardianship in light of Holy Scripture] his earlier study on the theme, a document that was accepted by the Transvaal Dutch Reformed Synod and the Council of Dutch Reformed Churches in 1947.

For the purposes of this article I want to attend more closely to Groenewald's text as found in Regverdige Rasse-apartheid. ${ }^{18}$ Groenewald

16 Albertyn, JR, Du Toit, P and Theron, H.S (eds.), Kerk en Stad: Verslag van Kommissie van Ondersoek oor Stadstoestande [Church and City: Report of the Commission of Inquiry into Urban Conditions] (Stellenbosch: Pro Ecclesia, 1947).

17 Volkskongres te Johannesburg 1-4 Julie 1947. Referate en Besluite [National Conference in Johannesburg 1-4 July 1947. Papers and Decisions], 124. Cf. for a discussion of the congress and report Vosloo, RR, From a farm road to a public highway: The Dutch Reformed Church and its changing views regarding the city and urbanisation in the first half of the $20^{\text {th }}$ century (1916-1947), Studia Historiae Ecclesiasticae XXXIX/2, December 2013:19-32.

18 For engagements with Groenewald's text cf., among others, Botha, AJ 1984, Die evolusie van 'n volksteologie (Bellville: UWK Drukkery), 198-201; Kinghorn, J (ed.) 1986, Die NG Kerk en apartheid (Johannesburg: Macmillan), 103-104; and Loubser, JA, 1987, 
starts by linking the argument for apartheid to the argument from history. The idea of apartheid, Groenewald states, is built on experiences stretching back through the generations. References are further made to the Mission Policy of 1935, which declares the church's opposition towards social "gelykstelling" and affirms the importance of the idea of guardianship. Groenewald also shows that the "Volkskongresse" in Bloemfontein in 1944 and in Johannesburg in 1947 affirmed the policy and practice of racial apartheid. Groenewald is aware that these ideas in defence of apartheid are also contested, hence he acknowledges that one also finds statements against the policy of apartheid and guardianship by those advocates of "justice" and "peace". Given these conflicting views, wisdom in this regard is to be sought not in the wisdom of the human being, but in God's Word as our tried and tested and infallible guideline ("as beproefte, onfeilbare rigsnoer"). ${ }^{19}$

Fortunately, or so Groenewald argues, Scripture is rich in statements that could provide fixed principles to guide us in this matter. The first point that Groenewald makes is the affirmation that Scripture teaches the unity of humanity. However, Scripture also teaches that diversity derives from God. In Genesis 10 we read that the nations were divided after the flood. And in Genesis 11we read that God created a confusion of languages through a deliberate deed (“'n bewuste daad"). Drawing on Acts 17:26, Groenewald sees not merely the separated nations but also the geographical area for each nation as part of the providence of God. Groenewald continues his argument by stating that only the nation that can maintain its (separate) identity can survive and be true to its divine destiny:

History ... confirms the truth that the peoples who protected their identity were able, in the name of the Lord, to bring blessing to themselves and their neighbours. Those who removed the divisions, perished. ${ }^{20}$

The Apartheid Bible: A Critical Review of Racial Theology in South Africa (Cape Town: Maskew Miller Longman), 61-69.

19 Cronje, G (with Nicol, W and Groenewald, EP), Regverdige Rasse-apartheid (Stellenbosch: Die Christen-Studenteverenigingsmaatskappy van Suid-Afrika, 1947), 43.

20 Cronje, Regverdige Rasse-apartheid, 48. 
Groenewald also argues that apartheid is not limited to one area of life, but extends to cover every aspect of life, including its national, social and religious aspects. Therefore Groenewald defends a national apartheid that respects the national borders between nations. The image of the vineyard in Isaiah 5 with its strong fence to secure safe growth is used to justify the argument. Without a fence wild boars will destroy the vineyard. Together with national apartheid, Groenewald also affirms social apartheid, since social assimilation leads to miscegenation, and that in turn leads to religious apostasy. This idea is also applied to marriage. Hence Groenewald's conclusion: "An unlimited social mixing with people who do not belong to your own community leads to moral and spiritual harm... There can only be communion for the sake of the gospel." ${ }^{21}$ This prohibition against social mixing is then further extended to the arenas of labour and jurisprudence. And with regard to religious apartheid, Groenewald feels that Scripture is so obvious in this regard that there is not a need to argue for it.

Groenewald admits that there are certain exceptions to the rule of national, social and religious apartheid to be found in Scripture. He refers to the assimilation of Rahab into Israel, the marriage of Ruth with Boaz, and the mixed descent of Timothy. But these exceptions do not disqualify the rule.

What is important to note is that the defence of apartheid is also placed within a broader "moral" argument. The decision to maintain apartheid in order to survive does not mean that a nation does not have any responsibility for others, specifically underdeveloped peoples ("met name teenoor 'n minderontwikkelde"). The affirmation of apartheid is coupled with the responsibility to act as guardian towards the less "mature" and "civilized" nations. But can this idea of guardianship be justified from the Bible? Here Groenewald refers to Galatians 4:2, where the word "guardian" or "ward" ("voog") occurs. The child, even if he is an heir, is placed under guardians and managers for a time determined by the father. The guardian is there only for a while, until the child reaches maturity. This idea is then extrapolated by Groenewald from the individual to nations. Groenewald, moreover, qualifies this relationship as follows: "One should add that no nation that accepts, in the name of the Lord and justice, guardianship

21 Cronje, Regverdige Rasse-apartheid, 54. 
over another should do so out of self-exaltation and as demonstration of superiority." ${ }^{22}$ But, continues Groenewald, there must be a certain response from the other, minor party in this relationship; they must show gratitude and respect to those who want to help them and lead them to maturity. ${ }^{23}$ Groenewald concludes his defence for racial apartheid and guardianship by stating "that the policy of apartheid and guardianship, as propounded by the Christian Afrikaner for non-whites, can be traced back to God's Word." ${ }^{24}$

The attempt to provide a scriptural justification for apartheid was also contested (as will be indicated in the next section of this article), but these ideas nevertheless made their way into official reports of the Dutch Reformed Church (such as the 1947 report of the Transvaal Synod of the DRC). It is therefore not surprising that in a series of editorials in Die Kerkbode (the official DRC newspaper) in September 1948 (a few months after the National Party won the general election with its slogan of "apartheid") could speak of apartheid as "church policy" ("kerklike beleid") and also challenge attempts to characterise apartheid as unscriptural. ${ }^{25}$ The Synod of 1949 accepted a report of the Committee on Race Relations that gave scriptural grounds for "our conception of the differences between and characteristics of the races." The gist of the report's findings lie in the statement that "the existence of the various races and nations was not only allowed by God, but was specifically willed and ordained by Him." ${ }^{26}$

\section{Critical voices against the biblical justification of apartheid: Ben Marais and Bennie Keet}

The attempt to give a biblical justification for apartheid found its fullest expression towards the end of the 1940s, albeit that earlier defences of apartheid as Scriptural could already be found in the late 1930s and early 1940s. But after 1944 more and more was written in this regard and the

22 Cronje, Regverdige Rasse-apartheid, 64.

23 Cronje, Regverdige Rasse-apartheid, 64.

24 Cronje, Regverdige Rasse-apartheid, 65.

25 See the editorials in Die Kerkbode, 22 September 1948, 664-665 and Die Kerkbode, 29 September 1948, 724-725.

26 See Acta Synodi Dutch Reformed Church, 1949: 459. 
public debate on these issues, for instance in Die Kerkbode, became more pronounced. ${ }^{27}$

One of the earliest critiques of the attempt to justify the racial policy of segregation came from Rev. Ben Marais (who later became professor in Church History at the University of Pretoria). Already on 10 April 1940 he had written a letter to Die Kerkbode saying that there is no Scriptural justification for apartheid. And at the Transvaal Synod in 1944 he questioned the view that apartheid is grounded on the principles of God's Word purporting to teach racial apartheid and the white man's role of guardian over the native. ${ }^{28}$ Marais wrote several articles and letters pertaining to this topic, but for our purposes here I want to focus mainly on two texts, namely an article in Op die Horison in June 1947 (which was an address at a conference for pastors held in March 1947 in Pretoria), and an article published in 1950 in Die Gereformeerde Vaandel ["The Reformed Banner" ${ }^{29}$

In an article "n Kritiese beoordeling van die Standpunt van ons Kerk insake Rasseverhoudings met die Oog op Gebeure Oorsee" [A critical evaluation of the view of our church regarding racial relations in the light of events abroad], published in 1947 in Op die Horison, Marais gives a clear statement of his views. He starts out by admitting that there are differences

27 See the letters on Scripture and racial apartheid by P.V. Pretorius (Die Kerkbode 2 June $1948,1279)$ and BJ Marais ( 14 July 1948, 1597), with both letters being critical of the attempt to defend apartheid on Scriptural grounds. This led to a strong polemic on "Die Skrif en Rasse-apartheid", with letters by JF Britz (Die Kerkbode, 4 August 1948, 265); FA Kock (Die Kerkbode, 4 August 1948, 267); "Uit Die Vrystaat: Die Bybel en Rasse-Apartheid" (Die Kerkbode, 11 August 1948, 301-302); JF Cilié (Die Kerkbode, 11 August 1948, 316); PJ Loots (Die Kerkbode, 11 August 1948, 316); EA Venter (Die Kerkbode, 11 August 1948, 317); SH Rossouw (Die Kerkbode, 25 August 1948, 441-443); RH Venter (Die Kerkbode, 8 September 1948, 572). This was followed by another letter from BJ Marais (Die Kerkbode, 15 September 1948:632-633) in which he responded to the criticisms of his position. See also further letters by LP Spies (Die Kerkbode, 29 September 1948, 747-748), EA Venter (Die Kerkbode, 6 October 1948, 807-808), and FA Kock (Die Kerkbode, 13 October 1948, 875-876). The correspondence was concluded with a letter by PV Pistorius (Die Kerkbode, 20 October 1948, 937-939). For more background on this correspondence, see also Van der Watt, PB 1987, Die Nederduitse Gereformeerde Kerk 1905-1975 (Pretoria: NG Kerkboekhandel), 90-91.

28 Cf. Van der Watt, Die Nederduitste Gereformeerde Kerk 1905-1975, 81.

29 Cf. Coetzee, MH 2010, Die 'kritiese stem' teen apartheidsteologie in die Ned Geref Kerk (1905-1974): 'n Analise van die bydraes van Ben Marais en Beyers Naudé (Wellington: Bybel-Media), 368-371. 
of opinion on this matter. He recalls his ecumenical experience in Madras in 1938, where it became clear to him that world Christianity would never accept or understand the Dutch Reformed Church's policy on race.

In reading Marais's text one has the feeling that he displays a more fully developed hermeneutical sensibility that some of his interlocutors. He writes, for instance: "I want to point out that our usual reference to the Old Testament in defence of apartheid is based on highly dubious grounds. We cannot simply transfer the prescriptions to Israel regarding 'separateness' to us or the English or the natives." ${ }^{30}$

Marais also held a different view of racial mixing from those of the defenders of apartheid on biblical grounds. Although he affirms that where there is a great difference in type, culture, civilization or religion, racial mixing is dangerous for several reasons, for Marais it is nevertheless untenable to make - on biblical grounds - the statement that God willed and divided the nations as a permanent and static situation. He continues: "There is today no race on earth without a mixed heritage. God built up, especially through racial mixing, a rich diversity of nations through the ages." ${ }^{1}$

Marais draws his arguments against the biblical justification of apartheid from what he refers to as the general principles of the Christian view of brotherhood ("Christelike broederskapsleer"), which was also the theme of his doctoral dissertation. ${ }^{32}$ God is the father of all people and they are all equal before God. The principle of the Kingdom is that of universalism. Therefore the church should be very careful in the way in which it justifies its racial policy with reference to Scripture and church history. Again Marais displays some hermeneutical caution and discernment:

The way in which the matter is stated in South Africa, as if it is a matter of doctrine that Scripture teaches apartheid between whites and blacks, is certainly far-fetched and ungrounded. We overburden Scriptural passages by applying them directly and in an unqualified

30 Marais, BJ, “' $n$ Kritiese beoordeling van die Standpunt van ons Kerk insake Rasseverhoudings met die Oog op Gebeure Oorsee," Op die Horison, 1947, 67.

31 Marais, “'n Kritiese beoordeling”, 48.

32 Marais, BJ, 1946. Die Christelike Broederskapsleer: Sy Agtergrond en Toepassing in die Vroeë Kerk (Unpublished $\mathrm{PhD}$ dissertation, Stellenbosch University, two volumes). Prof $\mathrm{BB}$ Keet was his promoter. 
manner to our situation. There are justified conclusions that we can reach. But we need to be careful. ${ }^{33}$

Marais further states: "The Christian must thus be careful not to reify and reverence the transient orders of family and volk, race and state, and view them as absolute." 34 Yet one should note that Marais did leave space for justifying racial apartheid "on the ground of very weighty practical considerations." ${ }^{35}$ Yet he added the following qualification: "But the requirement of Christian brotherhood should not be discarded and it should not be driven by racial self-interest or a sense of racial superiority." 36 Marais also challenges the idea of permanent guardianship ("ewigdurende voogdyskap"). This critique by Marais is certainly not at this stage a well-developed theological critique of the whole apartheid edifice. Yet his arguments were met with strong opposition, as is testified in the correspondence in Die Kerkbode following an extended letter that Marais wrote along similar lines to Die Kerkbode in 1948. ${ }^{37}$

Marais maintained and developed his argument in an article on "Die Skrif en Rassebeleid" [Scripture and Race Policy] in a volume of Die Gereformeerde Vaandel of 1950 which dealt with the apartheid issue ("die Apartheidsvraagstuk"). ${ }^{38}$ In this article Marais provides some hermeneutical pointers in dealing with this question. Marais points out the danger of wishful thinking that could lead us into accepting any argument as long as it fits into our position. ${ }^{39} \mathrm{He}$ also indicates the need to let Scripture speak as a whole. In addition, he called attention to the way in which the Dutch Reformed Church was totally isolated in holding its position, also from the broader ecumenical church and world Christianity.

33 Marais, "'n Kritiese beoordeling”, 70.

34 Marais, “'n Kritiese beoordeling”, 74.

35 Marais, “'n Kritiese beoordeling”, 75.

36 Marais, “'n Kritiese beoordeling”, 76.

37 See the reference to this correspondence in a footnote 27 in this article.

38 Marais, BJ, “Die Skrif en Rasse-apartheid," Die Gereformeerde Vaandel 18/1, February 1950:14-25.This edition of Die Gereformeerde Vaandel also includes articles by EA Venter on "Die Heilige Skrif en die Apartheidsvraagstuk", P.V. Pistorius "Ons Apartheidsbeleid en die Skrif" and A. van Schalkwyk on "Apartheid en die KerlikeGodsdienstige Lewe van die Bantoe".

39 Marais, "Die Skrif en Rasse-apartheid”, 15. 
Of special interest is the way in which Marais counters the argument made from history to justify apartheid (the argument that apartheid or segregation was the way of our fathers or previous generations) by going back in Church history (and especially to the early church) to indicate an alternative to the logic of separation.

Marais summarises his conclusion by arguing that Scripture does not emphasise racial apartheid, but the apartheid of $\sin ,{ }^{40}$ a point also made in his influential book of 1953 entitled Colour: Unsolved Problem of the West: "What Scripture emphasises is not racial apartheid, but apartheid as a result of sin." ${ }^{31}$ Marais also does not deny the idea of guardianship, but does challenge certain views that are often associated with this notion. $\mathrm{He}$ argues, for instance: "Let our first consideration be: Not how can I secure and maintain the rights and privileges of the whites, but how can I fulfil my duty as guardian in the light of Scripture." ${ }^{\prime 2}$

Another voice critical of the biblical justification of apartheid was that of Professor Bennie Keet, a theology professor at the Stellenbosch theological seminary. He attended the Synod of 1949 in Cape Town that accepted the report of the Committee on Race Relations, but could not participate in the discussion (since professors of theology were not official delegates). He did, however, write a four part series for Die Kerkbode in which he explicated his views. Keet is clearly sceptical of the statement of the report that the declared policy of apartheid would lead to the spiritual flourishing of blacks. ${ }^{43} \mathrm{He}$ is also highly critical of the way the report uses Scripture to justify political apartheid. Like Marais, Keet also finds the isolation of the Dutch Reformed Church on this topic regrettable, since the church is in danger of becoming sectarian. Keet also engages Groenewald's arguments in Regverdige Rasse-apartheid, and is clearly in agreement with the arguments and hermeneutical assumptions already put forward by Marais. Keet further challenges the narrow focus on the "Volk" as main identity marker when it comes to spiritual and national calling. With regard to the

40 Marais, "Die Skrif en Rasse-apartheid”, 16.

41 Marais, B.J 1953, Colour: Unsolved Problem of the West (Cape Town: Howard B. Timmins), 293.

42 Marais, "Die Skrif en Rasse-apartheid”, 25.

43 Keet, BB, “Die Heilige Skrif en Apartheid”, Die Kerkbode, 30 November 1949: 1005. 
calling of Christians, he comments: "We live out our calling not in the first place because we are Afrikaners, but because we are Christian-Afrikaners ... (W)ithout the qualification Christian we will have not a calling." 44 It should also be noted that Keet defended to some extent the notion of "kerklike apartheid" on practical grounds, but wants to keep the idea alive that the walls of separation can be broken down. Therefore he mentions in closing some initiatives at achieving unity, such as that the Dutch Reformed Mission Church ("Sendingkerk") be represented on the Federal Council ("Federale Raad"), as well as the need for the practice of joint celebration of the Lord's Supper by these churches divided along racial lines.

\section{The Bible, apartheid and identity constructions}

What can we learn from the way the Bible was read in the 1940s in South Africa to justify apartheid on biblical grounds as well as the attempts to critique this reading? Here one should tread carefully since the Bible was not read in the same way by the different proponents of a biblical justification of apartheid, and also not in the same way by those who critiqued apartheid. Yet it does seem as if certain identity constructions were at play in this regard. The various texts referred to above display an implicit or explicit understanding of the relationship between self and other, between sameness and difference, between identity and otherness. In conclusion I want to make a few hermeneutical remarks that is in my view pertinent in this regard.

\section{a) Beleaguered identity}

A close reading of the primary texts from the 1940s related to the theological justification and critique of apartheid reveals the challenges posed by the sense of what can be called "beleaguered identity." This is seen in the prevalence of the language of survival in these texts. Often the authors highlight the need for adopting a certain strategy vis-à-vis the other in order to survive or not to lose one's own identity. In addition, the language used for Africa as a zone of danger contributes to this sense of beleaguered identity (this is evident in Totius's and Strydom's depictions

44 Keet, BB, “Die Heilige Skrif en Apartheid”, Die Kerkbode, 14 December 1949, 1087. 
of "dark Africa"). In the 1940s the process of rapid Afrikaner urbanisation also led to competition with black labour, and the church's role was (in part at least) to create a type of enclave in which (rural) Afrikaner identity was protected and extended into the future. What are the implications of this for the way Scripture was read? The answer to this question is not all that clear, but I think that one could deduce that this context created an affinity for "survival texts" in which identity was protected through separation and segregation in order to survive. The anti-British empire language in many of the sermons during this time (see the sermons of C.R. Kotzé) also exemplifies this sense of a beleaguered identity. ${ }^{45}$ The argument is even made, as seen in the statement by Groenewald already referred to above, that history confirms the idea that peoples who protected their identity (through upholding divisions) were able to bring blessing to themselves and their neighbours.

\section{b) Fixed identity}

Another aspect that comes to the fore from reading these texts is the way in which identity was mostly understood in fixed categories. This understanding of identity as fixed and stable found expression in the aversion to blood mixing and bastardisation. This notion of a fixed identity is linked to the perception of beleaguered identity in the sense that in order to survive in a hostile situation the self and the group must remain "pure" and not be contaminated by the other. Any sense of identity as fluid or hybrid is completely absent in the writings of the proponents of the scriptural justification of apartheid. This fixed understanding of identity is often coupled with the romanticising of the Afrikaner bloodline, the so-called blood of the Huguenots and the Geuzen ("die Hugenote en die Geuse"). It is not surprising then that those texts which could possibly be used to affirm pure identity over against mixed identity would be pounced on in order to affirm a specific life and worldview. It is interesting that Ben Marais (as indicated in the discussion above) challenges such an identity construction when he deconstructs the critique against "blood mixing"

45 See Kotzé, Die Bybel en ons Volkstryd. In these sermons one finds the recurring emphasis on the need for strong walls to keep the nations apart. See, for instance, his sermon on "Die Volksmure" ("the walls of the Volk)", with Isaiah 60:18 as text (37-41). 
("bloedvermenging"), arguing that cultures and races are not static entities but that they have developed precisely through blood mixing.

\section{c) Isolationist identity}

Another feature of the texts arguing for the biblical justification of apartheid is the way in which they seem to flow from an understanding of identity as isolationist and hermetic. This is seen in the way that those who critique their reading are often depicted (including more critical ecumenical voices). One of the marks of Marais's and Keet's critique is that they seem to be aware of this isolation of the Dutch Reformed Church with regard to the policy of apartheid, and sees this as a serious call to introspection and internal critique. The greater ecumenical sensitivity of Marais and Keet seems to make them more aware of the ideological temptations operative when we read Scripture.

\section{d) Polarised identity}

Let me make a final remark with regard to identity constructions in the discourse on the scriptural defence of apartheid. A strong sense of "us" versus "them" characterised the discourse. This is in a sense ironic, since the Afrikaner struggled for internal unity during the time of the Second World War (in light of the divisions that emerged from the decision that South Africa should join the war on the side of Britain). ${ }^{46}$ So Totius could affirm the need to keep together what God has put together (the unity of the volk) and to separate what God has separated (the white and black races in South Africa). And it is interesting to note how other worldviews such as liberalism, Roman Catholicism and communism were viewed as dangerous for challenging the belief that there should be no equalisation ("geen gelykstelling") between races and no racial mixing.

\section{Conclusion}

Rereading the texts from the 1940s leaves on with the question about how our reading of the Bible is determined by beleaguered, fixed, isolationist and

46 Cf. Vosloo, RR Dealing with Division: Some Reponses to World War II within the Dutch Reformed Church on synodical and congregational level (1936-1944), Studia Historiae Ecclesiasticae XL/2: December 2014: 57-70. 
polarised identity constructions. And what difference does it make when we employ a hermeneutic marked by hospitality, hybridity, ecumenicity and reconciliation?

I have mixed feelings when reading these texts from the 1940s. It seems to me too easy to challenge the proponents of the biblical justification of apartheid as simply immoral or evil, or bad exegetes, or people who were merely pawns in the hand of politicians. The more haunting questions for me became: Why were these ideas received so favourably in the church? And: Why were the dissenting voices not heard more widely and, when they were, often scapegoated? And: Are we aware of our own ideological distortions as we appropriate the Bible for our seemingly good causes today? The need remains to grapple with these questions as we reflect on the uses and abuses of the Bible in public discourse today.

\section{Bibliography}

“Acta Synodi Dutch Reformed Church." 1949.

“Apartheid as Kerklike Beleid I.” Die Kerkbode, 22 September 1948, 664-665.

“Apartheid as Kerklike Beleid II.” Die Kerkbode, 19 September 1948, 724-725.

Albertyn, JR, Du Toit, P \& Theron, HS, eds. Kerk en Stad: Verslag van

Kommissie van Ondersoek oor Stadstoestande [Church and City:

Report of the Commission of Inquiry into Urban Conditions].

Stellenbosch: Pro Ecclesia, 1947.

Botha, AJ. Die Evolusie van 'n Volksteologie. Bellville: UWK Drukkery, 1984.

Brink, CB. "Die Betekenis van Christelike Voogdyskap." Op die Horison 6/2, June 1944, 50-58.

Britz, JF. “Die Skrif en Rasse-Apartheid.” Die Kerkbode, 4 August 1948.

Cilié, JF. “Die Skrif en Rasse-Apartheid.” Die Kerkbode, 11 August 1948.

Coetzee, MH. Die 'kritiese stem' teen apartheidsteologie in die Ned Geref

Kerk (1905-1974): 'n Analise van die bydraes van Ben Marais en Beyers

Naudé. Wellington: Bybel-Media, 2010. 
Cronje, G, Nicol, W and Groenewald, EP. Regverdige Rasse-apartheid. Stellenbosch: Die Christen-Studenteverenigingsmaatskappy van SuidAfrika, 1947.

"Die Rassebeleid van die Afrikaner: Besluite van die Volkskongres, Bloemfontein, September 1944." Op die Horison, March 1945 1, 16-23.

Du Toit, JD \& Du Toit, S. Die Afrikaanse Rassebeleid en die Skrif: Artikels van prof. dr JD du Toit en prof. $d r S d u$ Toit (tweede druk). Potchefstroom: Pro Rege Bpk, 1955.

Elphick, R. The Equality of Believers: Protestant Missionaries and the Racial Politics of South Africa. Pietermaritzburg: University of KwaZulu-Natal Press, 2012.

Gerdener, GBA. "Van die Redaksie,” Op die Horison 1/ 2, April 1939.

Keet, BB. "Die Heilige Skrif en Apartheid I." Die Kerkbode, 30 November 1949, 1004-1005.

Keet, BB “Die Heilige Skrif en Apartheid III.” Die Kerkbode, 14 December 1949, 1086-1087.

Kinghorn, J, ed. Die NG Kerk en Apartheid. Johannesburg: Macmillan, 1986.

Kock, FA. “Die Skrif en Rasse-Apartheid.” Die Kerkbode, 4 August 1948, 267.

Kock, FA. “Die Skrif en Rasse-Apartheid.” Die Kerkbode, 13 October 1948, 875-876.

Kotzé, CR. Die Bybel en ons Volkstryd: Preke 1930-1946. Bloemfontein: SACUM Beperk, nd.

Lombard, RTJ, ed. "Sendingbeleid van die Gefedereerde Ned. Geref Kerke, 1935.” Die Nederduitse Gereformeerde Kerke en Rassepolitiek, met spesiale verwysing na die jare 1948-1961. Pretoria: NGK Boekhandel, 1981.

Loots, PJ. “Die Skrif en Rasse-Apartheid.” Die Kerkbode, 11 August 1948, 316. Loubser, JA. The Apartheid Bible: A Critical Review of Racial theology in South Africa. Cape Town: Maskew Miller Longman, 1987. 
Marais, BJ. Die Christelike Broederskapsleer: Sy Agtergrond en Toepassing in die Vroeë Kerk. Unpublished PhD dissertation, Stellenbosch University, 1946.

Marais, BJ. "'n Kritiese beoordeling van die Standpunt van ons Kerk insake Rasseverhoudings met die Oog op Gebeure Oorsee." Op die Horison, 1947, 67.

Marais, BJ. “Die Skrif en Rasse-Apartheid.” Die Kerkbode, 14 July 1948, 1597.

Marais, BJ. “Die Skrif en Rasse-Apartheid.” Die Kerkbode, 15 September 1948, 632-633.

Marais, BJ. “Die Skrif en Rasse-Apartheid.” Die Gereformeerde Vaandel 18/1, 1950, 14-25.

Marais, BJ. Colour: Unsolved Problem of the West. Cape Town: Howard B Timmins, 1953.

Pistorius, PV. “Die Skrif en Rasse-Apartheid.” Die Kerkbode, 20 October 1948, 937-939.

Pretorius, PV. “Die Skrif en Rasse-Apartheid.” Die Kerkbode, 2 June 1948, 1279.

Rossouw, SH. “Die Skrif en Rasse-Apartheid.” Die Kerkbode, 25 August 1948, 441-443.

Spies, LP. “Die Skrif en Rasse-Apartheid.” Die Kerkbode, 29 September $1948,747-748$.

Strydom, JG. Die Rassevraagstuk en die toekoms van die blankes in SuidAfrika. NG Kerk in die OVS, nd.

"Uit Die Vrystaat: Die Bybel en Rasse-Apartheid.” Die Kerkbode, 11 August 1948, 301-302.

Van der Merwe, WJ. “Segregasie en Aparte Woongebiede.” Op die Horison, March, 1942, 15-22.

Van der Watt, PB. Die Nederduitse Gereformeerde Kerk 1905-1975. Pretoria: NG Kerkboekhandel, 1987. 
Venter, EA. "Die Skrif en Rasse-Apartheid.” Die Kerkbode, 11 August $1948,317$.

Venter, EA. “Die Skrif en Rasse-Apartheid.” Die Kerkbode, 6 October 1948, 807-808.

Venter, RH. "Die Skrif en Rasse-Apartheid." Die Kerkbode, 8 September 1948,572

"Volkskongres te Johannesburg 1-4 Julie 1947. Referate en Besluite." 1947.

Vosloo, RR. "From a farm road to a public highway: The Dutch Reformed Church and its changing views regarding the city and urbanisation in the first half of the $20^{\text {th }}$ century (1916-1947)." Studia Historiae Ecclesiasticae XXXIX/2 (2013): 19-32.

Vosloo, RR. "Dealing with Division: Some Reponses to World War II within the Dutch Reformed Church on synodical and congregational level (1936-1944)," Studia Historiae Ecclesiasticae XL/2: December 2014: 57-70. 